\title{
Urinary Neopterin Concentrations and T-Cell Subset Data in HIV-1 Infection
}

\author{
G. Reibnegger ${ }^{1,4}$, D. Fuchs ${ }^{1,4}$, J.J. Goedert ${ }^{2}$, A. Hausen ${ }^{1,4}$, A. Krämer ${ }^{2}$, E.R. Werner ${ }^{1,4}$, \\ G. Werner-Felmayer ${ }^{1,4}$, M.P. Dierich ${ }^{3,4}$, and H. Wachter ${ }^{1,4}$ \\ ${ }^{1}$ Institut für Medizinische Chemie und Biochemie, Universität Innsbruck, Österreich \\ ${ }^{2}$ National Cancer Institute, Bethesda, Maryland, USA \\ ${ }^{3}$ Institut für Hygiene, Universität Innsbruck, Österreich \\ ${ }^{4}$ Ludwig-Boltzmann-Institut für AIDS-Forschung, Innsbruck, Österreich
}

Summary. We investigated the ability of urinary neopterin concentrations and $\mathrm{T}$-cell subset data, and their ratios to discriminate between anti-HIV1 seronegatives, seropositives, and AIDS cases. Using receiver-operated-characteristics curves, neopterin levels were shown to provide the best discrimination. Of the ratios derived from the single variables, neopterin per CD4 + cell counts and neopterin per $\mathrm{CD} 4+/ \mathrm{CD} 8+$ cell ratio were superior to the $\mathrm{CD} 4+/ \mathrm{CD} 8+$ cell ratio. Multivariate analyses were performed using a generalized likelihood ratio approach as well as linear discriminant analysis. The combination of neopterin concentration and CD4 + T-cell count is well suited to discriminate between various stages of HIV-1 infection and, therefore, we recommend using more than one assay to evaluate disease progression.

Key words: Neopterin - T-cell subsets - HIV infection - Generalized likelihood ratio technique Classification

In subjects infected with human immunodeficiency virus type 1 (HIV-1), particularly in those free of overt clinical symptoms, staging and individual prognosis are important issues. Quantitation of Tcell subsets is widely employed for monitoring those infected with the HIV-1 virus, but changes are predominantly seen in later stages of the disease [5]. Increased concentrations of neopterin, a sensitive marker for the activation of the cell-mediated immune system, have been consistently found in HIV-1 infected individuals [6].

Abbreviations. HIV-1 = Human immunodeficiency virus type 1 ; $\mathrm{AIDS}=$ acquired immunodeficiency syndrome; $\mathrm{ROC}=$ receiver operated characteristics; $L R=$ likelihood ratio
In a cohort of Austrian homosexual men we have compared the behavior of neopterin concentrations in urine with T-cell subset data with regard to the discrimination between anti-HIV-1 seronegative and seropositive individuals [7]. Here we extend this study on another cohort: concentrations of neopterin in urine of American homosexual men were compared with T-cell subpopulation data and with several derived variables. We studied the potential of six single or composite variables to discriminate between three clinical conditions: antiHIV-1 seronegatives, anti-HIV-1 seropositives, and patients with overt AIDS. Notably, our study is not meant to replace serological testing. Rather, the roles of the studied variables, singly or combined, in different stages of the disease course should be better defined.

\section{Methods}

A cohort of 150 homosexual men was enrolled in the spring of 1982 as consecutive patients of three primary care physicians in Washington, D.C., and Manhattan, New York. Detailed patients characteristics were previously published $[9,10]$. Using samples collected during follow-up between April and August 1986, urinary neopterin concentrations were measured at Innsbruck, Austria, by an HPLC method (for review of analytical techniques, see Wachter [16]). An analysis of the predictive potential of neopterin levels in these patients has already been published [11].

For the present evaluation, we have included a subset of 144 of the 150 patients for whom complete records were available on concomitant measurements of neopterin, CD4+, and CD8 + T-cell number.

The patients were grouped into three categories for the present evaluation: 71 who were anti- 
HIV-1 seronegative at the time of sample collection, 64 anti-HIV-1 seropositives, and 9 individuals in whom overt AIDS was diagnosed at latest by the end of 1986 ( 5 of these had diagnosis of AIDS before the 1986 sample collection; in 4 subjects, AIDS was diagnosed within a few weeks after this investigation). In these 9 men, AIDS diagnosis was made due to occurrence of severe opportunistic infections; none of the patients, however, had a malignant disease.

\section{Statistical Methods}

In a first step, we computed for each of the three possible pairs of diagnostic categories (i.e., seronegatives vs seropositives, seronegatives vs AIDS cases, and seropositives vs AIDS cases), diagnostic sensitivities and specificities for each of the six investigated variables, using subsequently all measured values as cut-off limits. From these data, receiver operating characteristics (ROC) curves were constructed. As an aggregate measure for the diagnostic value, also the Youden index (sensitivity + specificity -1) was computed as a function of the variable investigated.

Second, we used a recently published procedure [13] for multivariate analysis of the potential of the variables to differentiate between the three diagnostic categories. This method yields formulae for estimating posterior probabilities for each diagnostic category, based on pretest probabilities for the categories and on weighting factors for laboratory test results (or other covariates). The weighting factors are obtained by logistic regression analysis. Briefly, for each pair of diagnostic categories, likelihood ratio functions are computed for single or combined laboratory (or clinical) tests by the logistic regression technique [1]. These functions are then used to convert pretest probabilities into posttest probabilities using a technique suited for more than two diagnostic categories [2]. The logistic regression analyses were performed using the BMDP computer software (program BMDPLR). For comparison, classical linear discriminant analyses were done using program BMDP7M. Statistical comparisons of frequencies (e.g., frequencies of correct classifications, or estimated indices of diagnostic value) were made using the following transformation:

$$
\begin{aligned}
z= & \left(\mid \arcsin \sqrt{p_{1}}\right. \\
& \left.-\arcsin \sqrt{p_{2}} \mid\right) /\left(28.648 \sqrt{\left(1 / n_{1}+1 / n_{2}\right)}\right),
\end{aligned}
$$

where $p_{1}, p_{2}$ are the two frequences to be compared, and $n_{1}$ and $n_{2}$ are the numbers of observations from which the frequency estimates were derived [15]. The $z$-values were assumed to follow a standard normal distribution.

\section{Results}

Differentiation Between Two Diagnostic Categories by Single or Composite Variables

Markedly higher mean neopterin concentrations and lower mean CD4 + T-cell numbers were noted among the HIV-1 seropositives, particularly those with AIDS (Table 1). ROC curves were computed for the three single and the three composite variables. The results for the differentiation between

Table 1. Measurement results and composite variables obtained in various diagnostic categories (figures are mean values, with range in parentheses)

\begin{tabular}{lcll}
\hline Variable $^{\mathrm{a}}$ & $\begin{array}{l}\text { Anti-HIV-1 } \\
\text { seronegatives } \\
(n=71)\end{array}$ & $\begin{array}{l}\text { Anti-HIV-1 } \\
\text { seropositives } \\
(n=64)\end{array}$ & $\begin{array}{l}\text { Patients with } \\
\text { AIDS } \\
(n=9)\end{array}$ \\
\hline $\begin{array}{l}\text { Neopterin } \\
\text { CD4+ T-cells }\end{array}$ & $\begin{array}{c}126(59,587) \\
\text { CD8+ T-cells }\end{array}$ & $\begin{array}{l}317(84,1316) \\
620(155,1359)\end{array}$ & $\begin{array}{l}900(445,1877) \\
225(38,550)\end{array}$ \\
$\begin{array}{l}\text { CD4+/CD8+ } \\
\text { T-cell ratio }\end{array}$ & $1.43(294,1313)$ & $846(335,2365)$ & $632(143,1316)$ \\
$\begin{array}{l}\text { Neopterin per } \\
\text { CD4+ T-cells }\end{array}$ & $0.139(0.050,1.142)$ & $0.632(0.138,3.71)$ & $9.414)$ \\
$\begin{array}{l}\text { Neopterin per } \\
\text { CD4+/CD8+ ratio }\end{array}$ & $95(31,336)$ & $0.77(0.22,1.83)$ & $0.18,0.70)$ \\
\hline
\end{tabular}

${ }^{a}$ Neopterin in urine: $\mu \mathrm{mol}$ per mol creatinine; CD4+ and CD $8+\mathrm{T}$-cell numbers per $\mu 1$ of peripheral blood 

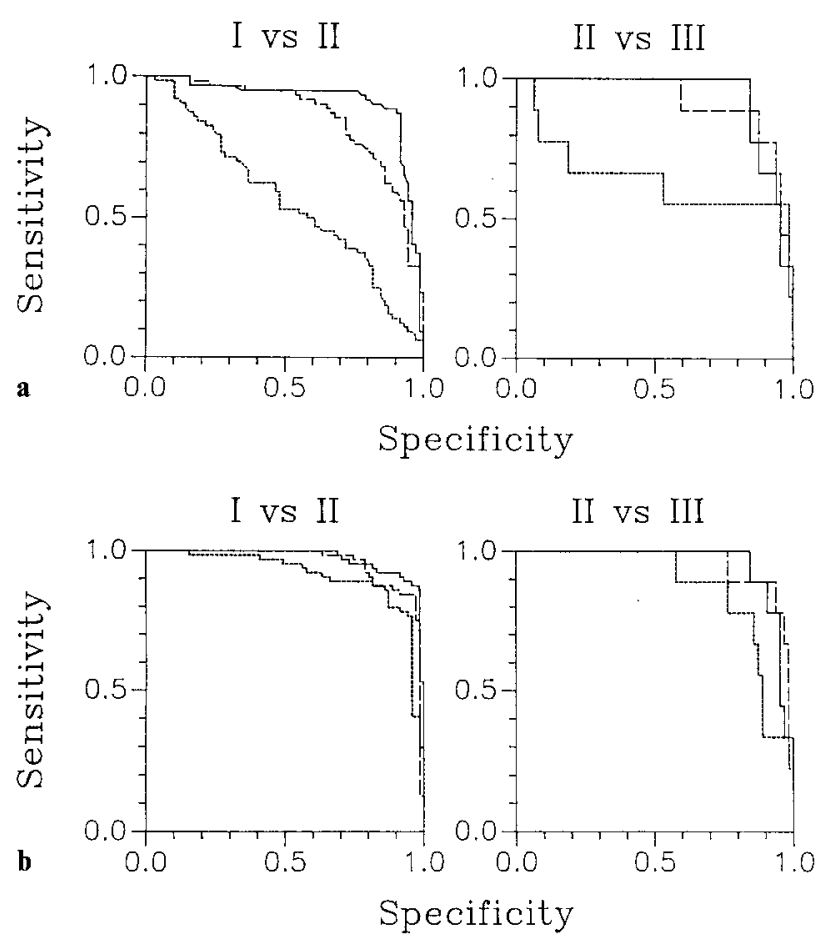

Figs. 1 a, b. ROC curves for discrimination between anti-HIV-1 seronegatives versus seropositives (I vS II) and seropositives versus AIDS cases (II vs III). A line following the equation sensitivity $=1-$ specificity would indicate a worthless test; the larger the deviation from this line (and the larger the area under the ROC curve) the better is the discriminative power of the test under scrutiny. Note that the results for the contrast II versus III can be regarded only as preliminary, since the number of AIDS cases in this study was very low a ROC curves for the single variables: urinary neopterin (solid line), $\mathrm{CD} 4+\mathrm{T}$-cell counts $(---)$, and CD $8+$ T-cell counts $(\ldots)$ ) b ROC curves for the composite variables: neopterin per CD4+/CD8 + T-cell ratio (solid line), neopterin per $\mathrm{CD} 4+\mathrm{T}$-cell count $(--)$, and $\mathrm{CD} 4+/ \mathrm{CD} 8+\mathrm{T}$-cell ratio $(\ldots .$.

anti-HIV-1 seronegatives versus seropositives and between seropositives and AIDS cases are shown in Fig. 1. Neopterin showed the greatest potential for differentiating anti-HIV-1 seronegatives and seropositives. For the differentiation of seropositives and AIDS cases, CD4 + T-cell number and neopterin had similar efficiency. In contrast, the CD8 + T-cell number did not discriminate between the diagnostic categories (Fig. $1 \mathrm{a}$ ).

Of the composite variables (Fig. $1 \mathrm{~b}$ ) the ratio neopterin per $\mathrm{CD} 4+/ \mathrm{CD} 8+$ discriminated best between seronegatives and seropositives. Importantly, using neopterin per CD4 $+\mathrm{T}$-cell count or neopterin per CD4+/CD8 + improved the discriminatory potential when compared with the common $\mathrm{CD} 4+/ \mathrm{CD} 8+$ ratio.

Optimal cut-off values for each variable were determined at the largest Youden index (Table 2). The conclusions are consistent with those from
Table 2. Diagnostic sensitivity and specificity for each variable, when pairwise comparisons between diagnostic classes are performed. Results are recorded at cut-off values defined by maximal Youden index

\begin{tabular}{lll} 
Variable $^{\mathrm{a}}$ & \multicolumn{2}{l}{ Groups compared } \\
\cline { 2 - 3 } & $\begin{array}{ll}\text { Seronegatives } \\
\text { vs sero- }\end{array}$ & Seropositives \\
positives & vs AIDS cases \\
\hline
\end{tabular}

1. Neopterin

\begin{tabular}{lcc} 
Optimal cut-off & 168 & 445 \\
Sensitivity & 0.89 & 1.00 \\
Specificity & 0.90 & 0.84 \\
CD4+ T-cells & & \\
Optimal cut-off & 859 & 355 \\
Sensitivity & 0.86 & 0.89 \\
Specificity & 0.72 & 0.88 \\
CD8+T-cells & & \\
Optimal cut-off & 925 & 483 \\
Sensitivity & 0.38 & 0.56 \\
Specificity & 0.79 & 0.98 \\
CD4+/CD8+ T-cell ratio & \\
Optimal cut-off & 1.068 & 0.587 \\
Sensitivity & 0.88 & 0.89 \\
Specificity & 0.86 & 0.77 \\
Neopterin per CD4+ & & \\
T-cell number & & \\
Optimal cut-off & 0.25 & 1.64 \\
Sensitivity & 0.84 & 0.89 \\
Specificity & 0.97 & 0.94 \\
Neopterin per CD4 $+/ C D 8+$ & \\
T-cell ratio & & \\
Optimal cut-off & 199 & 1.00 \\
Sensitivity & 0.88 & 0.84 \\
Specificity & 0.99 & \\
\hline
\end{tabular}

${ }^{a}$ Units see Table 1

Figs. $1 \mathrm{a}$ and $\mathrm{b}$ (note that statistical comparisons were made only for the contrast between seronegatives and seropositives; the number of AIDS patients was regarded too small to allow meaningful statistical tests): of the single variables, neopterin had the highest Youden index $(Y=0.79)$ which is significantly higher than the value found for CD4 + T-cell number $(Y=0.58, z=2.66$, two-sided $P$ value $=0.0078$. Of the composite variables, neopterin per $\mathrm{CD} 4+/ \mathrm{CD} 8+$ was best $(Y=0.87)$; this value being significantly higher than the result for $\mathrm{CD} 4+/ \mathrm{CD} 8+\mathrm{T}$-cell ratio $(Y=0.74, z=1.93$, $P=0.054)$. When the subjects were classified into three categories according to these optimal cut-off levels, the rate of correct classifications was $118 / 144(81.9 \%)$ for neopterin, $104 / 144(72.2 \%)$ for $\mathrm{CD} 4+, 110 / 144(76.4 \%)$ for $\mathrm{CD} 4+/ \mathrm{CD} 8+$, $125 / 144(86.8 \%)$ for neopterin per CD4 + , and for $124 / 144(86.1 \%)$ for neopterin per CD $4+/ C D 8+$. 
Table 3. Rate of correct classifications by various multivariate models using neopterin concentration and CD4+ T-cell number as variables

\begin{tabular}{|c|c|c|c|c|}
\hline & \multirow[b]{2}{*}{$\begin{array}{l}\text { Sero- } \\
\text { negatives }\end{array}$} & \multicolumn{3}{|c|}{ Correct classification } \\
\hline & & $\begin{array}{l}\text { Sero- } \\
\text { positives }\end{array}$ & $\begin{array}{l}\text { AIDS } \\
\text { cases }\end{array}$ & Total \\
\hline $\begin{array}{l}\text { 1. Linear discriminant analysis, } \\
\text { equal pretest probabilities } \\
\left(p_{1}=p_{2}=p_{3}=1 / 3\right)\end{array}$ & $\begin{array}{c}58 / 71 \\
(81.7 \%)\end{array}$ & $\begin{array}{l}49 / 64 \\
(76.6 \%)\end{array}$ & $\begin{array}{c}6 / 9 \\
(66.7 \%)\end{array}$ & $\begin{array}{l}113 / 144 \\
(78.5 \%)\end{array}$ \\
\hline $\begin{array}{l}\text { 2. Same as (1), but correct pretest probabilities } \\
\left(p_{1}=0.493, p_{2}=0.444, p_{3}=0.063\right.\end{array}$ & $\begin{array}{c}59 / 71 \\
(83.1 \%)\end{array}$ & $\begin{array}{l}51 / 64 \\
(79.7 \%)\end{array}$ & $\begin{array}{c}5 / 9 \\
(55.6 \%)\end{array}$ & $\begin{array}{l}115 / 144 \\
(79.9 \%)\end{array}$ \\
\hline $\begin{array}{l}\text { 3. Generalized likelihood ratio technique } \\
\left(p_{1}=p_{2}=p_{3}=1 / 3\right)\end{array}$ & $\begin{array}{c}63 / 71 \\
(88.7 \%)\end{array}$ & $\begin{array}{l}47 / 64 \\
(73.4 \%)\end{array}$ & $\begin{array}{c}8 / 9 \\
(88.9 \%)\end{array}$ & $\begin{array}{l}118 / 144 \\
(81.9 \%)\end{array}$ \\
\hline $\begin{array}{l}\text { 4. Generalized likelihood ratio technique } \\
\left(p_{1}=0.493, p_{2}=0.444, p_{3}=0.063\right)\end{array}$ & $\begin{array}{c}65 / 71 \\
(91.5 \%)\end{array}$ & $\begin{array}{l}54 / 64 \\
(84.4 \%)\end{array}$ & $\begin{array}{c}5 / 9 \\
(55.6 \%)\end{array}$ & $\begin{array}{l}124 / 144 \\
(86.1 \%)\end{array}$ \\
\hline
\end{tabular}

For the analyses described here, the patients were divided into three categories ( 71 seronegatives, 64 seropositives without AIDS, 9 AIDS patients). First, by linear discriminant analysis using neopterin and CD4 + data, it was attempted to define classification functions allowing classification of patients to the correct diagnostic category (classification functions not shown). This was done twice, assuming two different sets of pretest probabilities $(1,2)$. As mentioned in the text, for each set of pretest probabilities separate discriminant analysis was necessary. Second, the same classification problem was treated using a recently described combination of a generalized likelihood ratio procedure and logistic regression analysis [13] which is described in some detail in the text. Again, two different sets of pretest probabilities were used $(3,4)$. Logistic regression analysis was necessary only once, recalculation for different pretest probabilities was done using formulae given in the text. Notably, both neopterin and $\mathrm{CD} 4+$ data were shown by discriminant analysis as well as by logistic regression analysis to be jointly significant, indicating that both variables added significant information.

\section{Multivariate Approach to Differentiate All Three Diagnostic Categories}

Analyzing in turn each of the three binary combinations of the diagnostic categories, we performed logistic regression analyses using neopterin $(x)$ and CD4 + T-cell count $(y)$ as covariates. Thus, we obtained the following formulae for the logarithmic likelihood ratio functions $[\log (L R)]$ :

Seronegatives vs seropositives:

$$
\begin{aligned}
\log \left(L R_{12}\right)= & -0.020856 x+0.0046371 y \\
& -0.039983-\log (71 / 64)
\end{aligned}
$$

Seronegatives vs AIDS cases:

$\log \left(L R_{13}\right)=-0.0079255 x+0.013438 y$

$$
-2.76710-\log (71 / 9)
$$

Seropositives vs AIDS cases:

$$
\log \left(L R_{23}\right)=-0.0035428 x+0.0092473 y
$$

$$
+0.03967-\log (64 / 9)
$$

In these formulae, the logarithmic terms are needed to correct the constant terms for unequal frequencies of the diagnostic categories [1]; the weighting factors of the variables are the regression coefficients obtained by the logistic regression analyses.

Using these results and the relationship $L R_{i j}=$
$1 / L R_{j i}$, and assuming either equal or observed pretest propabilities $p_{1}, p_{2}, p_{3}$ for the three diagnostic categories, posttest probabilities $P_{1}, P_{2}$ and $P_{3}$ were calculated for each subject inserting his individual test results into the following formulae [2]:

$$
\begin{aligned}
P_{1}= & 1 /\left[1+1 /\left(L R_{12} \cdot p_{1} / p_{2}\right)\right. \\
& \left.+1 /\left(L R_{13} \cdot p_{1} / p_{3}\right)\right] \\
P_{2}= & 1 /\left[1+1 /\left(L R_{21} \cdot p_{2} / p_{1}\right)\right. \\
& \left.+1 /\left(L R_{23} \cdot p_{2} / p_{3}\right)\right] \\
P_{3}= & 1 /\left[1+1 /\left(L R_{31} \cdot p_{3} / p_{1}\right)\right. \\
& \left.+1 /\left(L R_{32} \cdot p_{3} / p_{2}\right)\right]
\end{aligned}
$$

For comparison, linear discriminant analyses were done on the same data set, whereby neopterin and $\mathrm{CD} 4+\mathrm{T}$-cell count were used as covariates. The rate of misclassfications was smallest when the described generalized likelihood ratio approach based on the logistic regression technique was used, and when the observed pretest probabilities were inserted (Table 3).

\section{Discussion}

This study confirms and extends results obtained on another cohort [7]: In patients infected with the HIV-1 virus and in persons belonging to groups at high risk for HIV-1 disease, neopterin 
concentrations are of use to discriminate anti-HIV1 seronegatives, seropositives without AIDS, and those with overt disease. For the discrimination between seronegatives and seropositives, neopterin was found to be superior to the CD4 + T-cell count. This difference was less expressed in the discrimination between seropositives and AIDS cases: here both variables offered a nearly perfect discrimination. This is in accord with the common experience that CD4 + T-cell counts are particularly low in advanced stages of the disease.

Naturally, this study is not meant to replace serologic testing for HIV-1 for the diagnosis of the infection. Rather, it may be possible to define the roles of the various potential indicators of disease progression. It must be stressed that our study suffers from the fact that the number of patients with AIDS is very low; therefore, the conclusions about the discrimination between seropositives without and with AIDS should be viewed as preliminary.

The results are compatible with previous reports demonstrating a significant potential of neopterin concentrations and CD4+ T-cell numbers for prediction of the further course of disease in HIV-1 infected individuals. Serum [3] as well as urine concentrations of neopterin $[8,12]$ were found to aid significantly in the prognosis of HIV-1 infection, and similar results were found in a study of the prognostic value of neopterin in the present patients [11].

It has been proposed that the ratio between neopterin and CD4 + T-cells might offer advantages in assessing prognosis [4], and this has been extended and confirmed in another cohort [8]. Additionally it has been shown by Cox regression analysis that the combination of both variables has better predictive value than each single variable [12]. To define the behavior of the suggested composite variable in our patients, we have included neopterin per CD4 + T-cell count and, additionally, neopterin per $\mathrm{CD} 4+/ \mathrm{CD} 8+$ in the present analysis. Our results indicate, that these variables are superior to neopterin or CD4 $+\mathrm{T}$-cell number singly, and also to the common CD4 + /CD8 + Tcell ratio for monitoring progress of HIV disease.

In addition to the univariate evaluations by means of ROC curves and Youden indices, we were interested in the construction of a decision rule allowing conversion of pretest probabilities of the three diagnostic categories into posttest probabilities based on measurements of neopterin concentrations and CD4 + T-cell counts. The model used $[13,14]$ has been shown to yield a high rate of correct classifications when applied to our data set. It seems to be superior to linear discriminant analysis, and it has the advantage that it is most easily transportable to situations with quite different pretest probabilities. This important adjustment is not as easily done for the linear discriminant models. There, a new computation of the model is necessary for a new clinical setting, whereas the generalized likelihood ratio approach requires only adjustment of the constant terms but not a new logistic regression. Superiority to linear discriminant analysis is probably due to greater robustness of the logistic approach against deviations of the distribution of values from multinormality.

From the present study in combination with a variety of investigations by us and others the conclusion seems justified that neopterin measurement may be useful in the routine management of individuals infected with HIV-1. This simple biochemical marker for the activation of the cellmediated immune system offers a sensitive and noninvasive tool for assessing the patient's clinical status and, as shown in other investigations, the prognosis. In combination with clinical information, an accurate system for staging HIV-1 disease will probably be obtainable through the use of laboratory assays likely to include CD4 + T-cell count, neopterin, $\beta-2$ microglobulin, and HIV-1 p-24 antigen or antibody. Although further work is needed, to define the role for combinations of each of those markers, we have demonstrated that combined testing with CD4 + T-cell counts and neopterin is superior to each test used individually.

\section{References}

1. Albert A (1982) On the use and computation of likelihood ratios in clinical chemistry. Clin Chem 28:1113-1119

2. Birkett NJ (1988) Evaluation of diagnostic tests with multiple diagnostic categories. J Clin Epidemiol 41:491-494

3. Bogner JR, Matuschke A, Heinrich B, Eberle E, Goebel F-D (1988) Serum neopterin levels as predictor of AIDS. Klin Wochenschr 66:1015-1018

4. Crocchiolo PR, Lizioli A, Bedarida G, Panzeri MP (1988) CD4+: neopterin ratio significantly improves correlation with the Walter Reed staging system if compared with CD4+ and neopterin considered separately. AIDS 2:481-482

5. Eyster ME, Gail MH, Ballard JO, Al-Mondhiry H, Goedert JJ (1987) Natural history of human immunodeficiency virus infections in hemophiliacs: effects of T-cell subsets, platelet counts, and age. Ann Intern Med 107:1-6

6. Fuchs D, Hausen A, Reibnegger G, Werner ER, Dierich MP, Wachter H (1988) Neopterin as a marker for activated cell-mediated immunity: application in HIV infection. Immunol Today $9: 150-155$

7. Fuchs D, Banekovich M, Hausen A, Hutterer J, Reibnegger G, Werner ER, Gschnait F, Dierich MP, Wachter H (1988) Neopterin estimation compared with the ratio of $T$-cell subpopulations in persons infected with human immunodeficiency virus-1. Clin Chem 34:2415-2417 
8. Fuchs D, Spira TJ, Hausen A, Reibnegger G, Werner ER, Werner-Felmayer G, Wachter H (1989) Neopterin as a predictive marker for disease progression in human immunodeficiency virus type 1 infection. Clin Chem 35:1746-1749

9. Goedert JJ, Biggar RJ, Winn DM, Mann DL, Byar DP, Strong DM, DiGioia RA, Grossmann RJ, Sanchez WC, Kase RG, Greene MH, Hoover RN, Blattner WA (1985) Decreased helper $T$ lymphocytes in homosexual men: I. Sexual contact in high incidence areas for the acquired immunodeficiency syndrome. Am J Epidemiol 121:629 636

10. Goedert JJ, Biggar RJ, Winn DM, Mann DL, Byar DP, Strong DM, DiGioia RA, Grossmann RJ, Sanchez WC, Kase RG, Greene MH, Hoover RN, Blattner WA (1985) Decreased helper $\mathrm{T}$ lymphocytes in homosexual men: II. Sexual practices. Am J Epidemiol 121:637-644

11. Krämer A, Wiktor SZ, Fuchs D, Milstien S, Gail MH, Yellin FJ, Biggar RJ, Wachter H, Kaufman S, Blattner WA, Goedert JJ (1989) Neopterin: a predictive marker of acquired immunodeficiency syndrome in human immunodeficiency virus infection. J AIDS 2:291-296

12. Melmed RN, Taylor JMG, Detels R, Bozorgmehri M, Fahey JL (1989) Serum neopterin changes in HIV-infected subjects: indicator of significant pathology, CD4 T cell changes, and the development of AIDS. J AIDS 2:70-76

13. Reibnegger G, Fuchs D, Hausen A, Werner ER, WernerFelmayer G, Wachter H (1989) Generalized likelihood ratio concept and logistic regression analysis for multiple diagnostic categories. Clin Chem 35:990-994

14. Reibnegger G, Fuchs D, Hausen A, Werner ER, WernerFelmayer G, Wachter H (1989) Generalization of the likelihood ratio concept for diagnostic tests with multiple diagnostic categories. J Clin Epidemiol 42:477-478

15. Sachs L (1984) Angewandte Statistik, 6th edn. Springer, Berlin Heidelberg New York Tokyo, p 263

16. Wachter H, Fuchs D, Hausen A, Reibnegger G, Werner ER (1989) Neopterin as marker for activation of cellular immunity: immunologic basis and clinical application. Adv Clin Chem 27:81-141

Received : July 11, 1989

Returned for revision: September 12, 1989

Accepted: September 25, 1989

Prof. Dr. Dr. H. Wachter

Institut für Medizinische Chemie

und Biochemie der Universität Innsbruck

Ludwig-Boltzmann-Institut für AIDS-Forschung

Fritz-Pregl-Str. 3

A-6020 Innsbruck, Österreich

\section{Buchbesprechungen}

Bönner, G., Rahn, K.H.: Prostacyclin und Hypertonie. Springer, Berlin Heidelberg New York London Paris Tokyo Hong Kong 1988. X, 90 S., 43 Abb., 4 Tab., brosch. DM 22,-

Das Buch Prostacyclin und Hypertonie wendet sich im Vorwort an einen breiten Leserkreis: es will ,jedem interessierten Arzt und Forscher helfen, sich ein eigenes Bild von der physiologischen und pathophysiologischen Bedeutung des vaskulären Prostaglandin $\mathrm{PGI}_{2} \mathrm{zu}$ machen". Das Inhaltsverzeichnis zeigt dann, daß es sich um einen umfassenden und detaillierten Bericht über die Erkenntnisse seit der Entdeckung des $\mathrm{PGI}_{2} 1976$ bis 1987 handelt. Durch eine straffe Gliederung, eine persönliche Stellungnahme am Ende jeden Kapitels und ein umfangreiches Literaturverzeichnis wurde versucht, einerseits das wissenschaftlich genaue Detail, andererseits die für den interessierten Arzt notwendige Übersicht zu erzielen. - Folgerichtig werden zunächst die Biochemie und Pharmakologie des $\mathrm{PGI}_{2}$, das Wirkprofil und schließlich die Bedeutung des $\mathrm{PGI}_{2}$ bei verschiedenen Formen der Hypertonie behandelt. Das Thema ist besonders schwierig, da bis vor einigen Jahren offensichtlich falsch hohe Werte für $\mathrm{PGI}_{2}$ gemessen wurden, derzeit immer noch große Unterschiede zwischen In-vitro- und In-vivo-Befunden bestehen und überdies meist noch unklar ist, bei welchen Prozessen $\mathrm{PGI}_{2}$ tatsächlich eine pathophysiologische Bedeutung hat. Der mit der Literatur nach 1987 vertraute Leser kann sich oft der Meinung der Autoren nicht anschließen, da besonders bei Patienten mit Arteriosklerose häufig erhöhte $\mathrm{PGI}_{2}$-Plasmakonzentrationen berichtet werden. - Es bedarf der gründlichen Fachkenntnis, übersichtlich das komplexe Gebiet der Interaktionen zwischen den vasopressorischen und vasorelaxierenden Hormonen, welche den aktuellen Blutdruck bedingen, darzustellen. Dies ist den Autoren geglückt. Besonderer Wert wurde auf die Bedeutung der vasorelaxierenden Komponente bei der Blutdruckregulation gelegt. Die einzelnen Befunde sind durch ein umfangreiches Literaturverzeichnis mit 275 Stellen belegt, welche alphabetisch geordnet sind. Sehr selten kommt es dadurch zu falschen Literaturangaben (S. 29, Tab. 2). Der Druck und die Ausstattung mit Tabellen lassen nichts zu wünschen übrig. - Insgesamt leidet das Buch an dem hohen Anspruch, einem so weiten Personenkreis genügen zu wollen. Es bietet auf engstem Raum dem Leser eine umfassende Information über die Ergebnisse der Prostacyclinforschung bis 1987. Die weitergehenden Erkenntnisse konnten natürlich nicht berücksichtigt werden. Durch die Fülle der Information ist das Buch nicht immer leicht $\mathrm{zu}$ lesen, die übersichtliche Gliederung hilft aber bei der Orientierung und läßt eine gezielte Information mit Hilfe des umfangreichen Sachverzeichnisses zu.

O. Adam (München) 